\title{
Seed mass effects on germination and growth of diverse European Scots pine populations
}

\author{
P.B. REICH ${ }^{1}$ \\ University of Minnesota, Department of Forest Resources, 1530 North Cleveland Avenue, \\ St. Paul, MN 55108, U.S.A. \\ J. OLEKSYN \\ University of Minnesota, Department of Forest Resources, 1530 North Cleveland Avenue, \\ St. Paul, MN 55108, U.S.A. \\ and \\ Polish Academy of Sciences, Institute of Dendrology, Parkowa 5, PL-62-035 Kórnik, Poland \\ AND \\ M.G. TJOELKER \\ University of Minnesota, Department of Forest Resources, 1530 North Cleveland Avenue, \\ St. Paul, MN 55108, U.S.A.
}

Received March 22, 1993

Accepted July 23, 1993

\begin{abstract}
Reich, P.B., Oleksyn, J., and TJoelKer, M.G. 1994. Seed mass effects on germination and growth of diverse European Scots pine populations. Can. J. For. Res. 24: 306-320.

Seedlings of 24 European Scots pine (Pinus sylvestris L.) populations were grown in controlled environment chambers under simulated photoperiodic conditions of 50 and $60^{\circ} \mathrm{N}$ latitude to evaluate the effect of seed mass on germination and seedling growth characteristics. Seeds of each population were classified into 1-mg mass classes, and the four classes per population with the highest frequencies were used. Photoperiod had minimal influence on seed mass effects. Overall, seed mass was positively related to the number of cotyledons and hypocotyl height. Populations differed significantly in seed mass effect on biomass. In northern populations $\left(55-61^{\circ} \mathrm{N}\right)$, dry mass at the end of the first growing season was little affected by seed mass. However, dry mass in 9 of 15 central populations $\left(54-48^{\circ} \mathrm{N}\right)$ and all southern $\left(<45^{\circ} \mathrm{N}\right)$ populations correlated positively with seed mass. Relative growth rate was not related to seed mass within or across populations, and thus early growth is largely determined by seed mass. Relative growth rate also did not differ among populations, except for a geographically isolated Turkish population with the highest seed mass and lowest relative growth rate. After one growing season, height was positively correlated $\left(r^{2}>0.6\right)$ with seed mass in 15 populations. To check the duration of seed mass effects, height growth of $1-$ to 7-year-old field experiments established with the same seed lots were compared. Seed mass effects on height were strongest for 1-year-old seedlings and declined or disappeared by the age of 5-7 years among central and southern populations, but remained stable over that time in northern populations.
\end{abstract}

Reich, P.B., Olekisyn, J., et TJoelker, M.G. 1994. Seed mass effects on germination and growth of diverse European Scots pine populations. Can. J. For. Res. 24 : 306-320.

Les semis de 24 populations européennes de pin sylvestre (Pinus sylvestris L.) ont été cultivés dans des chambres à environnement contrôlé, en simulant des conditions de photopériode correspondant à 50 et $60^{\circ} \mathrm{N}$., dans le but d'évaluer l'effet du poids des graines sur les paramètres de germination et de croissance des semis. Les graines de chaque population furent réparties en classes de poids de $1 \mathrm{mg}$ d'intervalle et, dans chaque population, les quatre classes avec la plus forte fréquence furent utilisées. La photopériode a eu peu d'influence sur les effets du poids des graines. Dans l'ensemble, le poids des graines était positivement relié au nombre de cotylédons et à la hauteur de l'hypocotyle. L'effet du poids des graines sur la biomasse variait de façon significative selon la population. Chez les populations nordiques $\left(55\right.$ à $61^{\circ} \mathrm{N}$.), le poids sec à la fin de la première saison de croissance était peu affecté par le poids des graines. Cependant, le poids sec de 9 des 15 populations centrales ( 54 à $48^{\circ} \mathrm{N}$.) et de toutes les populations méridionales $\left(<45^{\circ} \mathrm{N}\right.$.) réagissait positivement au poids des graines. Le taux relatif de croissance n'était pas relié au poids des graines à l'intérieur ou entre les populations. La croissance initiale est par conséquent largement déterminée par le poids des graines. Le taux relatif de croissance ne différait pas non plus parmi les populations, à l'exception d'une population géographiquement isolée de Turquie qui avait les graines les plus lourdes et le plus faible taux relatif de croissance. Après une saison de croissance, la hauteur était positivement corrélée $\left(r^{2}>0,6\right)$ avec le poids des graines dans 15 populations. La croissance en hauteur a été comparée dans des dispositifs au champ âgés de 1 à 7 ans et établis à partir des mêmes lots de graines dans le but de vérifier la durée des effets du poids des graines. Les effets du poids des graines sur la hauteur étaient le plus marqué chez les semis de 1 an et ont diminué ou sont disparus vers l'âge de 5 à 7 ans chez les populations centrales et méridionales, mais sont demeurés stables pendant ce temps chez les populations nordiques.

[Traduit par la rédaction]

\section{Introduction}

Reports concerning the effect of seed size or mass on germination, early development and physiology of woody plants

\footnotetext{
${ }^{1}$ Author to whom all correspondence should be addressed. Printed in Canada / Imprimé au Canada
}

are inconsistent. In some studies a positive correlation was observed between seed size and seedling size (Righter 1945; Perry 1976; Dunlap and Barnett 1983). In others, seed mass was largely unrelated to or explained only a small part of growth variation (Gailis 1973; Lines 1974; Mann 1979; 
Szczygiel 1981; Dormling and Johnsen 1992). It has also been shown across species that relative growth rate (RGR) is often negatively related to seed mass (Westoby et al. 1992). Data on the duration of the effect of seed size on plant growth is also scant, with estimates ranging between 1 and 35 years or more (Busse 1931; Nanson 1970; Giertych 1974; Mikola 1980, 1985). Therefore, the persistence of seed mass effects could effectively mask other genetic differences and confound conclusions based on early tests (Giertych and Oleksyn 1992).

Seed size fractionation is a common practice used to increase uniformity in seedling size (Lindgren 1982; Campbell and Sorensen 1984), and vigorous growth in the early years is considered important in avoiding suppression in plantations, while keeping tending costs low (Zheltov 1974). However, there are concerns that size grading, which normally removes light seeds, may reduce the genetic diversity of a seed 1ot (Hellum 1976; Silen and Osterhaus 1979; Lindgren 1982). It was also noted that phenotypically less valuable (minus) trees tend to produce seeds with higher mass than normal or phenotypically more valuable (plus) trees in the same stand (Ehrenberg et al. 1955). Reports on the influence of seed mass on rates of germination and emergence in Scots pine (Pinus sylvestris L.) are contradictory. Some studies found a positive correlation between the rate of germination and seed mass (Simak and Gustafsson 1954), whereas other studies have not (Zaborovskii 1966; Mikola 1985).

The marked variation of seed mass of Scots pine populations with geographical latitude has been repeatedly confirmed (Pravdin 1969). In the north where winter climatic conditions are more severe and temperature during the growing season is lower, mean seed mass is usually lower than in central and southern parts of the species range.

In this paper we report on seed mass, germination, and various growth characteristics of geographically diverse European provenances of Scots pine. We focus primarily on a controlled environment experiment designed specifically to examine variation in seed mass within and among populations in relation to seedling growth, but which also had controlled photoperiod conditions of 50 and $60^{\circ} \mathrm{N}$ latitude as part of a broader study of photoperiodic effects on growth (Oleksyn et al. 1992). In addition, we also used data from existing "common garden" plantations, established with the same seed sources (identical seed lots) used in this experiment, to evaluate the relationships between seed mass and plant height growth under natural growing conditions.

\section{Materials and methods}

\section{Plant material and growth conditions}

Seeds of Scots pine were collected from 24 European stands (Table 1). Eighteen populations were obtained between 1978 and 1980 by the International Union of Forest Research Organizations (IUFRO) Working Party "Scots pine provenances and breeding" (Oleksyn 1988). Six additional populations from Russia and Ukraine were collected in 1987. All seeds were stored at $3^{\circ} \mathrm{C}$ in the phytotron chambers at the Institute of Dendrology in Kórnik, Poland.

Seed mass distributions were determined for each population. One hundred randomly chosen seeds were individually weighed and classified in one of eight 1-mg mass classes from 3.1 to $11.0 \mathrm{mg}$ (i.e., class $1,3.1-4.0 \mathrm{mg}$; class $2,4.1-5.0 \mathrm{mg}$; etc.). For each population the four mass classes with the highest frequencies were selected for this experiment. These classes generally accounted for over $90 \%$ of the mass distribution. In population
15 from Sweden, seeds were distributed mainly between 3.1 and $6.0 \mathrm{mg}$; therefore only three mass classes were used.

Seeds were soaked in distilled water $24 \mathrm{~h}$ before sowing in $0.35 \mathrm{~L}, 10 \mathrm{~cm}$ diameter, pots containing an $80: 20 \%$ quartz sand forest soil $(\mathrm{v} / \mathrm{v})$ mixture. The surface of the medium in each pot was partitioned into four sectors in which three seeds of each mass class were sown to a depth of $0.5 \mathrm{~cm}$. Eight pots with 12 seeds, representing the four mass classes, were sown for each population. The pots were watered daily with a modified halfstrength Hoagland's solution. Two weeks after sowing and near completion of germination, all pots were treated with a metalaxyl fungicide (Ridomil 2E, Ciba-Geigy) in order to prevent damping-off. Plants were thinned to a maximum of eight per pot after germination was complete.

Four pots of each population were placed in each of two controlled environmental growth chambers (Conviron model E-15, Winnipeg, Manitoba, Canada). Germination occurred under a $16 \mathrm{~h}$ day : $8 \mathrm{~h}$ night cycle. During germination, photosynthetic photon flux density at pot level was $286 \pm 21 \mu \mathrm{mol} \cdot \mathrm{m}^{-2} \cdot \mathrm{s}^{-1}$ and was provided by two $1000-\mathrm{W}$ metal-halide and two $1000-\mathrm{W}$ sodium lamps (GTE Sylvania). Throughout the entire experiment, air temperature in the chambers were maintained at $20 \pm 0.1$ (day) and $17 \pm 0.1^{\circ} \mathrm{C}$ (night) and relative humidities at $60 \pm 3$ (day) and $70 \pm 3 \%$ (night).

Following completion of germination at 22 days after sowing, two photoperiod treatment regimes were initiated. Based on the day lengths (sunrise to sunset) of the Smithsonian Meteorological Tables (List 1958), the chambers were programmed to simulate the natural daylength changes from May 1 to September 1 at 50 and $60^{\circ} \mathrm{N}$ latitude. The photoperiod treatments were changed at 4-day intervals to track the changing day length. In addition to the latitudinal daylengths regimes, a diurnal light treatment was introduced and modified every 4 days, so that the maximum and total integrated quantum flux were the same among the two photoperiod treatments and the daily pattern was as similar as possible given the difference in daylength.

The experiment consisted of a factorial combination of 24 populations and two photoperiods in a completely randomized design with four seed mass classes within each population. The four seed mass classes were replicated in four pots as described above. Within the two chambers, environmental conditions (irradiance, relative humidity, and temperature) were monitored daily and there were no significant differences between chambers. However, to further randomize possible chamber effects, all pots were rotated within each chamber and among chambers when photoperiod treatments were switched between the chambers every 4 days.

The mass of the main parts of the seeds: seed coat, megagametophyte, and embryo, of three populations from Poland (provenance 9), Sweden (provenance 15) and Ukraine (provenance 22) were separately measured on a randomly chosen sample of 25 seeds of each population. The number of germinated seeds for each population and mass class was recorded every day starting from the beginning of germination at nine days after sowing for all populations. At the end of the experiment (after $\approx 20$ weeks) all plants were harvested; separated into roots, primary and secondary needles, and stems; oven dried at $65^{\circ} \mathrm{C}$; and weighed. Mean relative growth rate was calculated from seed mass to dry mass at harvest. For all variables, differences between treatments and populations were analyzed using analysis of variance (general linear model procedures, SAS Institute Inc., Cary, N.C.). Since the number of seed mass classes was low (four in all but one population), trends for seed mass effects on parameters within population are reported at the $p<0.1$ level. Since little interaction between photoperiod and seed mass was found, all presented data were pooled across photoperiod, unless shown separately.

To check the duration of seed mass effects on height growth of different Scots pine provenances, we used data for 1- to 7-year- 
TABLE 1. The origin of seeds of Scots pine used in the study

\begin{tabular}{|c|c|c|c|c|c|c|c|}
\hline \multirow[b]{2}{*}{ Region } & \multicolumn{2}{|r|}{ Provenance } & \multirow[b]{2}{*}{ Country } & \multirow{2}{*}{$\begin{array}{l}\text { Lat. } \\
(\mathrm{N})\end{array}$} & \multirow{2}{*}{$\begin{array}{l}\text { Long. } \\
\text { (E) }\end{array}$} & \multirow{2}{*}{$\begin{array}{l}\text { Altitude } \\
\text { (m) }\end{array}$} & \multirow{2}{*}{$\begin{array}{c}\text { Mass of } \\
1000 \text { seeds }(\mathrm{g})\end{array}$} \\
\hline & No. & Origin $^{a}$ & & & & & \\
\hline \multirow{7}{*}{$\begin{array}{l}\text { North } \\
\qquad\left(>55^{\circ} \mathrm{N}\right)\end{array}$} & 1 & Roshchinskaya Dacha & Russia & $60^{\circ} 15^{\prime}$ & $29^{\circ} 54^{\prime}$ & 80 & 5.1 \\
\hline & 15 & Sumpberget & Sweden & $60^{\circ} 11^{\prime}$ & $15^{\circ} 52^{\prime}$ & 185 & 4.4 \\
\hline & 2 & Kondezhkoe & Russia & $59^{\circ} 58^{\prime}$ & $33^{\circ} 30^{\prime}$ & 70 & 5.3 \\
\hline & 3 & Serebryanskoe & Russia & $58^{\circ} 50^{\prime}$ & $29^{\circ} 07^{\prime}$ & 80 & 5.6 \\
\hline & 26 & Ostrovskij & Russia & $57^{\circ} 50^{\prime}$ & $28^{\circ} 09^{\prime}$ & 50 & 5.6 \\
\hline & 27 & Sebyezhskij & Russia & $57^{\circ} 40^{\prime}$ & $28^{\circ} 10^{\prime}$ & 50 & 5.7 \\
\hline & 4 & Silene & Latvia & $55^{\circ} 45^{\prime}$ & $26^{\circ} 40^{\prime}$ & 165 & 5.8 \\
\hline \multirow{16}{*}{$\begin{array}{l}\text { Central } \\
\qquad\left(54-48^{\circ} \mathrm{N}\right)\end{array}$} & 5 & Milomlyn & Poland & $53^{\circ} 34^{\prime}$ & $20^{\circ} 00^{\prime}$ & 110 & 5.3 \\
\hline & 6 & Suprasl & Poland & $53^{\circ} 12^{\prime}$ & $23^{\circ} 22^{\prime}$ & 160 & 6.6 \\
\hline & 10 & Neuhaus & Germany & $53^{\circ} 02^{\prime}$ & $13^{\circ} 54^{\prime}$ & 40 & 7.7 \\
\hline & 11 & Betzhorn & Germany & $52^{\circ} 30^{\prime}$ & $10^{\circ} 30^{\prime}$ & 650 & 6.8 \\
\hline & 9 & Bolewice & Poland & $52^{\circ} 24^{\prime}$ & $16^{\circ} 03^{\prime}$ & 90 & 6.2 \\
\hline & 7 & Spala & Poland & $51^{\circ} 37^{\prime}$ & $20^{\circ} 12^{\prime}$ & 160 & 6.2 \\
\hline & 23 & Khrenovsk & Ukraine & $51^{\circ} 10^{\prime}$ & $42^{\circ} 00^{\prime}$ & 150 & 8.6 \\
\hline & 8 & Rychtal & Poland & $51^{\circ} 08^{\prime}$ & $17^{\circ} 55^{\prime}$ & 190 & 5.7 \\
\hline & 13 & Ardennes & Belgium & $50^{\circ} 46^{\prime}$ & $4^{\circ} 26^{\prime}$ & 110 & 9.0 \\
\hline & 22 & Zhitomir & Ukraine & $50^{\circ} 30^{\prime}$ & $28^{\circ} 15^{\prime}$ & 300 & 8.0 \\
\hline & 12 & Lampertheim & Germany & $50^{\circ} 00^{\prime}$ & $10^{\circ} 00^{\prime}$ & $95-100$ & 6.6 \\
\hline & 25 & Tsherkasy $\mathrm{II}^{b}$ & Ukraine & $49^{\circ} 31^{\prime}$ & $32^{\circ} 30^{\prime}$ & 50 & 7.6 \\
\hline & 21 & Tsherkasy I & Ukraine & $49^{\circ} 30^{\prime}$ & $32^{\circ} 10^{\prime}$ & 50 & 8.9 \\
\hline & 14 & Haguenau & France & $48^{\circ} 49^{\prime}$ & $7^{\circ} 47^{\prime}$ & $130-180$ & 6.6 \\
\hline & 16 & Zahorie & Slovakia & $48^{\circ} 46^{\prime}$ & $17^{\circ} 03^{\prime}$ & 160 & 8.1 \\
\hline & 17 & Pornoapati $^{b}$ & Hungary & $47^{\circ} 20^{\prime}$ & $16^{\circ} 28^{\prime}$ & 300 & 8.2 \\
\hline \multirow{3}{*}{$\begin{array}{l}\text { South } \\
\qquad\left(<45^{\circ} \mathrm{N}\right)\end{array}$} & 19 & Prusacka Rijeka & Montenegro & $44^{\circ} 05^{\prime}$ & $17^{\circ} 21^{\prime}$ & $800-970$ & 7.1 \\
\hline & 18 & Maocnica & Bosnia & $43^{\circ} 10^{\prime}$ & $19^{\circ} 30^{\prime}$ & 1200 & 6.6 \\
\hline & 20 & Catacik & Turkey & $40^{\circ} 00^{\prime}$ & $31^{\circ} 10^{\prime}$ & $1380-1420$ & 9.0 \\
\hline
\end{tabular}

NOTE: Provenances are ordered and grouped by latitude of origin. Provenances 3 and 17 were not used in the controlled environment study.

${ }^{a}$ Provenances with numbers 1-20 = SP IUFRO 1982 and were used in the field experiments presented in this paper.

${ }^{b}$ Seed orchard.

old plants (from same seed sources) in the SP IUFRO 1982 experiment (Table 1), located in Poland and Croatia (Kociecki 1985; Oleksyn 1988; Gracan 1989; Gunia and Zybura 1987, 1989; Matras 1989; Gunia et al. 1991; Rzeznik 1991).

\section{Results}

The seed masses of the Scots pine provenances used in this study as well as the results of a literature survey indicate a strong relationship $\left(r^{2}=0.63, p<0.001\right)$ between the latitude of origin and the mass of seeds (Fig. 1). The lightest seeds originate from northern latitudes $\left(>60^{\circ} \mathrm{N}\right)$ and the heaviest from southern latitudes $\left(<50^{\circ} \mathrm{N}\right)$. Apparently there is no relation between longitude or altitude of seed stand and the mass of seeds (Fig. 1). The general trend of highaltitude provenances of Scots pine having the heaviest seeds seems to be mainly driven by southern pines from montane sites that are characterized by larger seeds (Fig. 1). No relationship between seed mass and altitude exists within populations grouped by northern, central, or southern origin. The masses of Scots pine seeds varied within populations, and the seed mass distributions were approximately normal (Fig. 2). Populations from the central and especially the southern part of the species range tended to have a broader seed mass distribution than those from the northern part of the range.

The seed of Scots pine and other pines is composed of three main parts: coat, megagametophyte, and embryo. These parts comprised approximately 25,66 , and $9 \%$ of the total mass of the seed, respectively. As shown in Fig. 3, these parts vary in mass among populations and from seed to seed, but their relative contributions to total seed mass over the range of seed masses are constant (Fig. 3).

\section{Germination}

Overall mean germination of seeds averaged $66 \%$, and ranged from $28 \%$ for provenance 10 (Germany) to $100 \%$ for provenance 15 (Sweden). There were no clear latitudinal trends in percent germination or in average germination time (defined as a number of days to $90 \%$ germination) when comparing all populations, and thus ignoring differences in seed mass among populations (Table 2). Similarly, mean percent of germination was not related to seed mass classes, when data for all populations were included (and thus ignoring differences in percent germination due to populations). However, both seed mass and latitude of origin were related to percent germination after accounting for the confounding of seed mass and latitude. For instance, when compared at similar mass classes, the percentage of germination was greater on average in central, and southern populations than in northern populations (Fig. 4), and average germination percent for northern, central, and southern population groups showed a linear decrease with increasing seed mass $\left(r^{2}=\right.$ $0.92,0.80$, and 0.45 respectively; Fig. 4). The same pattern 

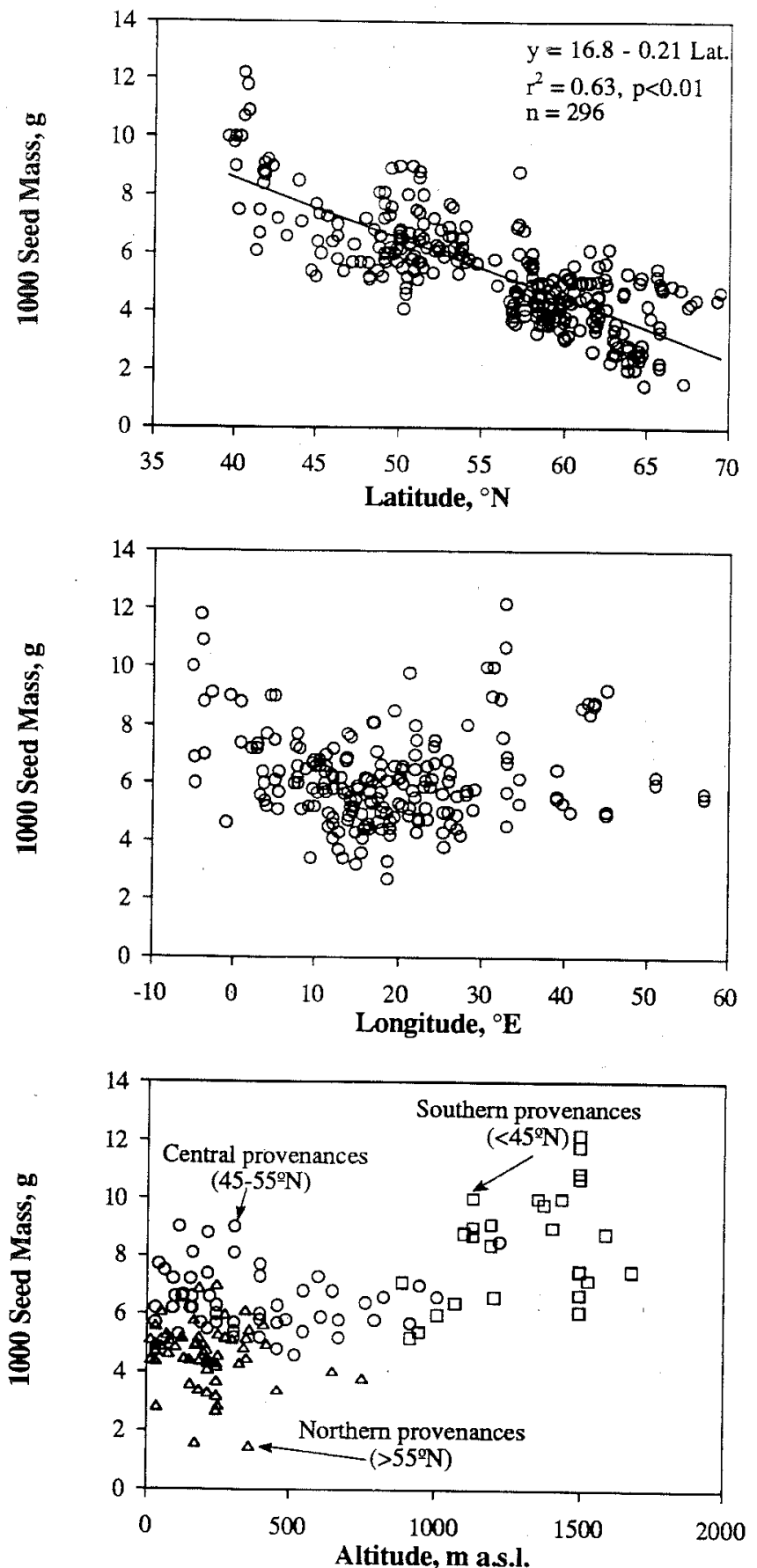

FIG. 1. Variation in mean seed mass (of 1000 seeds) among Scots pine populations in relation to latitude, longitude, and altitude of origin. Populations in this study are combined with those of a broad literature survey (Schotte 1906; 1910; Kurdiani 1912; Tyszkiewicz 1939; Razumov 1940, as cited in Pravdin 1969; Wright and Bull 1963; Saatçioglu 1967; Pravdin 1969; Urbanski 1978; Puliainen and Lajunen 1984). a.s.l., above sea level.

was significant within 3 of 24 provenances, but within the others percent germination was highly variable.

\section{Early growth characteristics}

Seed mass was correlated with Scots pine seedling growth at early stages of development. The mean number of cotyledons varied from 5.2 for populations 2 and 27 (northern Russia) to 6.3 for population 13 (Belgium) (Table 3). The mean length of cotyledons ranged from $1.9 \mathrm{~cm}$ for popula-

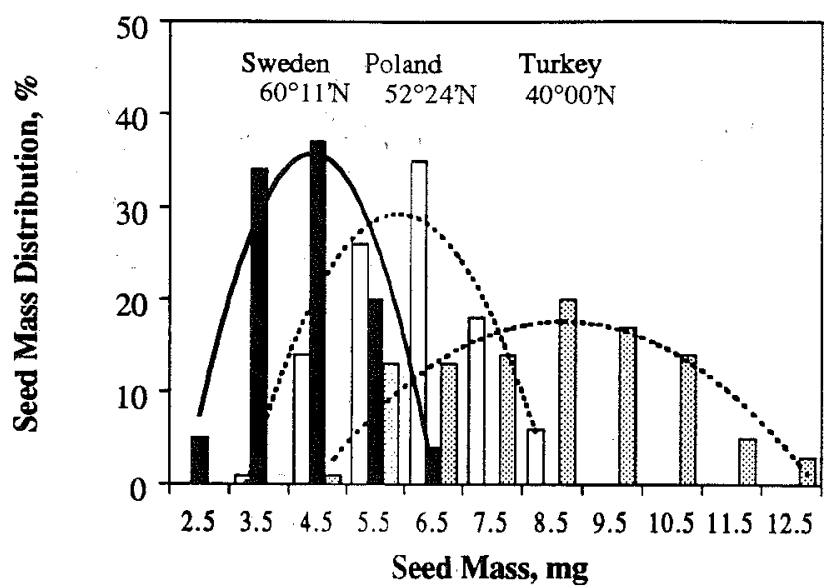

FIG. 2. Relative frequency distribution of seed mass within three populations of Scots pine, originating from a broad latitudinal range from Sweden, Poland, and Turkey. Midpoints of $1.0-\mathrm{mg}$ mass class intervals are shown.
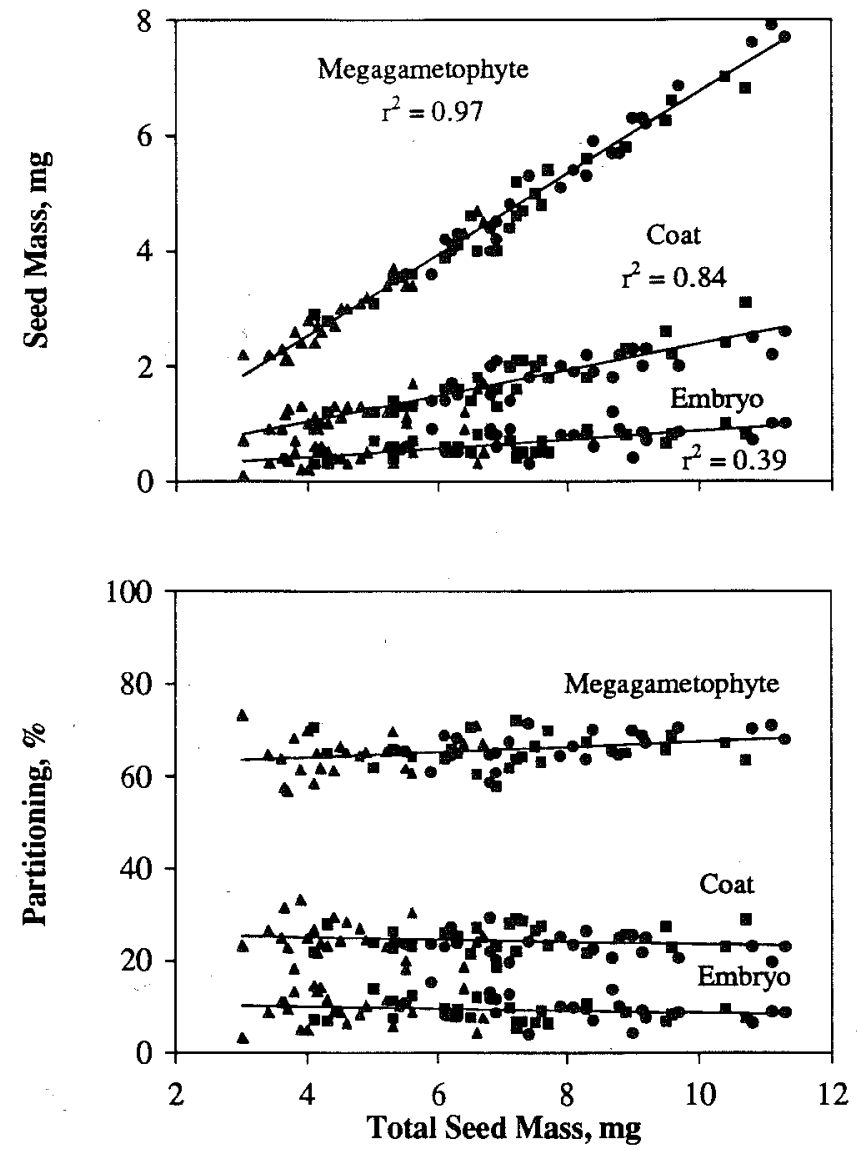

FIG. 3. Dry mass and partitioning to megagametophyte, seed coat, and embryo in relation to total seed mass within and among three Scots pine populations (provenance 15, Sweden (४), provenance 9, Poland ( $\mathbf{m})$, and provenance 22, Ukraine (•) from diverse latitudinal origin ( $n=25$ seeds per population).

tion 2 (Russia) to 2.9 for population 23 (Ukraine) (Table 4). Mean hypocotyl height varied between $1.7 \mathrm{~cm}$ (population 15, Sweden) to $2.6 \mathrm{~cm}$ (population 13, Belgium) (Table 5).

When pooling across populations, there were statistically significant positive relations between seed mass and number of cotyledons $\left(r^{2}=0.63, \mathrm{p}<0.01\right)$, cotyledon length $\left(r^{2}=\right.$ $0.66, p<0.01)$, and hypocotyl height $\left(r^{2}=0.50, p<0.01\right)$ 
TABLE 2. Average percent germination and germination time for European Scots pine populations in relation to variation in seed mass

\begin{tabular}{|c|c|c|c|c|c|c|c|c|c|c|c|}
\hline \multirow[b]{2}{*}{ Region } & \multirow{2}{*}{$\begin{array}{l}\text { Provenance } \\
\text { No. }\end{array}$} & \multicolumn{8}{|c|}{ Mean percent germination for seed mass classes $(\mathrm{mg})$ : } & \multirow{2}{*}{$\begin{array}{l}\text { Mean } \\
\text { germination } \\
(\%)\end{array}$} & \multirow{2}{*}{$\begin{array}{l}\text { Average } \\
\text { germination } \\
\text { time (days) }\end{array}$} \\
\hline & & $3.1-4.0$ & $4.1-5.0$ & $5.1-6.0$ & $6.1-7.0$ & $7.1-8.0$ & $8.1-9.0$ & $9.1-10.0$ & $10.1-11.0$ & & \\
\hline \multirow{6}{*}{$\begin{array}{l}\text { North } \\
\qquad\left(>55^{\circ} \mathrm{N}\right)\end{array}$} & 1 & 54 & 63 & 70 & 79 & & & & & 67 & 14.0 \\
\hline & 15 & 100 & 100 & 100 & & & & & & 100 & 9.0 \\
\hline & 2 & & 50 & 46 & 42 & & & & & 48 & 12.0 \\
\hline & 26 & & & 42 & 46 & 33 & 50 & & & 43 & 12.0 \\
\hline & 27 & & 50 & 50 & 46 & 25 & & & & 43 & 13.0 \\
\hline & 4 & & 79 & 62 & 83 & 87 & & & & 78 & 12.0 \\
\hline \multirow{15}{*}{$\begin{array}{l}\text { Central } \\
\qquad\left(54-48^{\circ} \mathrm{N}\right)\end{array}$} & 5 & & 92 & 100 & 100 & 100 & & & & 98 & 11.0 \\
\hline & 6 & & & 79 & 67 & 54 & 67 & & & 67 & 12.0 \\
\hline & 10 & & & 21 & 33 & 37 & 21 & & & 28 & 14.0 \\
\hline & 11 & & & 70 & 62 & 50 & 58 & & & 60 & 13.5 \\
\hline & 9 & & 83 & 75 & 96 & 97 & & & & 85 & 11.0 \\
\hline & 7 & & & 83 & 75 & 91 & 87 & & & 84 & 11.0 \\
\hline & 23 & & & & & 46 & 46 & 62 & 37 & 48 & 9.0 \\
\hline & 8 & & 83 & 75 & 92 & 83 & & & & 83 & 11.0 \\
\hline & 13 & & & & & 46 & 42 & 42 & 46 & 44 & 13.5 \\
\hline & 22 & & & & 87 & 91 & 83 & 75 & & 84 & 10.0 \\
\hline & 12 & & 58 & 62 & 71 & 62 & & & & 63 & 14.5 \\
\hline & 25 & & & & 92 & 50 & 67 & 71 & & 70 & 10.0 \\
\hline & 21 & & & & & 50 & 50 & 42 & 21 & 41 & 12.0 \\
\hline & 14 & & & 46 & 62 & 42 & 37 & & & 47 & 11.0 \\
\hline & 16 & & & & 92 & 79 & 79 & 79 & & 82 & 11.0 \\
\hline \multirow{3}{*}{$\begin{array}{l}\text { South } \\
\qquad\left(<45^{\circ} \mathrm{N}\right)\end{array}$} & 19 & & & 79 & 62 & 75 & 71 & & & 72 & 10.0 \\
\hline & 18 & & & 75 & 79 & 83 & 87 & & & 81 & 11.0 \\
\hline & 20 & & & & 71 & 67 & 54 & 71 & & 66 & 13.0 \\
\hline Mean & & 69 & 76 & 67 & 72 & 64 & 60 & 63 & 35 & 66 & $11.7 \pm 1.6$ \\
\hline $\begin{array}{l}\text { Population effect } \\
p>F^{a}\end{array}$ & & 0.0001 & 0.0001 & 0.0001 & 0.0001 & 0.0001 & 0.0001 & 0.0132 & 0.2248 & 0.0001 & \\
\hline
\end{tabular}

NOTE: Average germination time was calculated as a number of days to $90 \%$ germination. Seed mass effects were significant only for populations $21(p=0.10), 25(p=0.03)$, and $27(p=0.07)$ ${ }^{a}$ Based on analysis of variance of population effects within each seed mass class in this and subsequent tables. 
(Tables 3-5). These positive relations were also observed within latitudinal groupings (northern, central, and southern) (Fig. 5), and within most populations when examined individually. A greater mean number of cotyledons occurred in southern $(6.0 \pm 0.2)$ and central $(5.8 \pm 0.3)$ than northern $(5.4 \pm 0.2)$ populations. At all seed masses, central populations had slightly longer cotyledons and shorter hypocotyl heights than northern populations.

A summary of ANOVA for seed mass effects on dry mass components and proportional dry mass distribution of Scots pine seedlings after the end of the growing season is shown in Table 6. Total plant dry mass was not significantly $(p>0.1)$ affected by seed mass for all six northern populations $\left(>55^{\circ} \mathrm{N}\right)$. In contrast, in all three southern populations $\left(<45^{\circ} \mathrm{N}\right)$ seed mass was positively related to dry mass of roots $(p \leq 0.05)$ and total plant mass $(p<0.1)$. Of the 15 populations from the central European range of Scots pine, nine showed significant $(p<0.1)$ effects of seed mass on shoot, root or total plant dry mass. Except for two central populations, there were no effects of seed mass on root or needle proportional dry mass allocation. Relative growth rate was not related to seed mass within or across populations and did not differ among populations, except for the Turkish provenance, which had the highest seed mass and lowest relative growth rate.

At harvest, height was positively related to seed mass in 15 populations $\left(r^{2}>0.6\right)$ at the 50 or $60^{\circ} \mathrm{N}$ photoperiod or both (in 9 of those 15 populations, $r^{2}>0.8, p<0.1$; Table 7). Two populations $(6$, Poland $)$ at $50^{\circ} \mathrm{N}$ and $(21$, Ukraine $)$ at $60^{\circ} \mathrm{N}$ showed a negative relation between seed mass and height (Table 7). In addition, photoperiod affected the relationship between seed mass and final height in nine populations (from all population groups), where seed mass effects were evident in only one photoperiod treatment or changed from a positive to a negative slope. Across populations, seed mass was positively correlated with seedling height at 50 but not at $60^{\circ} \mathrm{N}$ (Fig. 6). However, this correlation is probably unrelated to any biological seed mass effect. Instead variation in mean seed mass among populations is correlated with latitude of origin (see Fig. 1) and the length of the height growth period in populations from different latitudes was differentially influenced by photoperiod (Oleksyn et al. 1992). Thus, at $50^{\circ} \mathrm{N}$ photoperiod conditions, populations from the north (which have smaller seeds) had substantially shorter height growth periods (and total height growth) than central and southern populations. At $60^{\circ} \mathrm{N}$ photoperiod conditions, height growth period was not consistently different among northern, central, and southern populations, and there was no relationship between seed mass and height growth (Fig. 6).

\section{Relationships between seed mass and height in field plots}

Correlation coefficients between seed mass and total height growth showed the disappearance of the seed mass effects with time when examining all populations as a group. Depending on the site, the correlation between seed mass and total height growth of all populations was significant until 2-5 years from planting (Table 8). The correlation coefficient for the final year of data at each site (years 5-7) was half or less than the correlations observed earlier (years $1-4)$. In contrast, in examining northern populations (1, 2, 3 (Russia); 4 (Latvia); 15 (Sweden)) separately as a group, the relationship between seed mass and total height did not

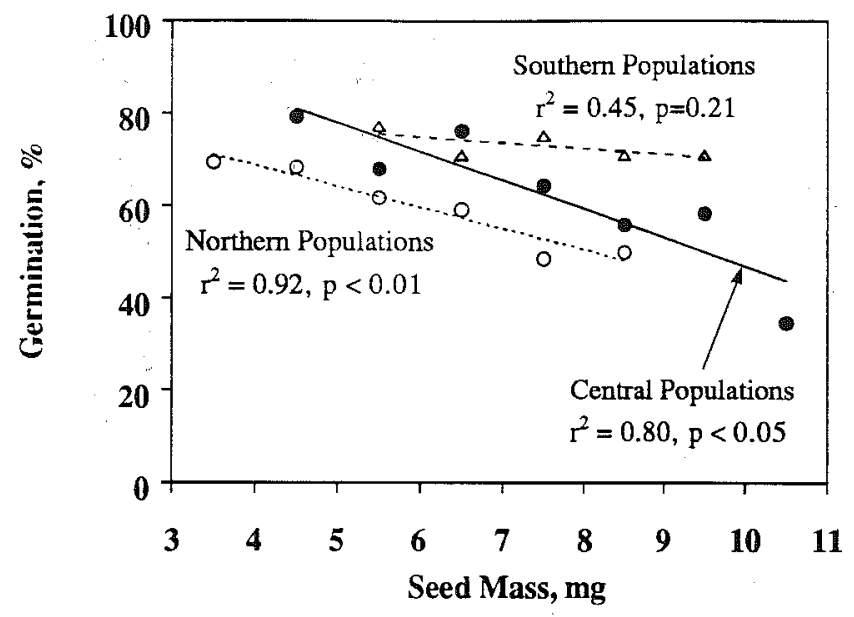

FIG. 4. Mean percent germination in relation to seed mass for northern, central, and southern population groups of Scots pine.

decline over time at any site, and remained high $\left(r^{2}>0.8\right)$ after 5-7 years.

Year to year correlations within locations and site to site correlations between locations indicate that populations vary in height in consistent ways at these sites. Within locations, correlations between the height of 1-year-old seedlings and height in following years either gradually disappeared (Supras1), or became weaker but remained significant (other 3, sites; Table 9). Height of 5- to 7-year-old trees at any given site was better correlated with height of similar aged than 1-year-old trees at other sites (Table 9). Thus, despite the influence of site quality on height growth, predicting performance at other sites based on one experimental plot will be better using 5- to 7-year-old trees, once seed mass effect is minimized, than using 1-year-old seedlings, in which effects of site quality and genetic effects are minimized and seed mass maximized.

At Suprasl, ranking of tree heights changed with time, reflecting the disappearance of seed mass effects (Fig. 7). From age 1 to 6 years, ranking of the three southern populations (latitude $<45^{\circ} \mathrm{N}$ ) declined (from 6 th to 10 th) to the three lowest rankings (18th to 20th). The two next most southern populations $\left(14\right.$ and $\left.16,48-49^{\circ} \mathrm{N}\right)$ also decreased in rank over time. Four central populations $(9,8,4$, and 6 , $51-56^{\circ} \mathrm{N}$ ) showed the biggest increases in rank, and most northern populations also increased in rank.

\section{Discussion}

Seed mass of Scots pine differs with latitude of stand origin. In general, seeds in the northern part of the species range have less mass than in the southern part (Fig. 1). This type of gradual decrease in Scots pine seed mass from north to south has been reported previously (Wright and Bull 1963; Pravdin 1969). Similar negative relationships between seed mass and latitude of origin were found also for other tree species, such as Pinus strobus L. (Genys 1968), Pinus contorta Dougl. ex Laws (Maschning 1971), Larix decidua Mill. (Sindelar 1974), Pseudotsuga menziesii (Mirb.) Franco (Birot 1972) and Picea abies (L.) Karst. (Fober and Giertych 1968).

Short growing seasons and low nutrient availability in the northern part of the species range are the factors likely responsible for smaller seed mass and longer gaps between seed years (Chapin 1980; Pulliainen and Lajunen 1984). 
TABLE 3. Mean number of cotyledons for European Scots pine populations in relation to seed mass variation

\begin{tabular}{|c|c|c|c|c|c|c|c|c|c|c|c|}
\hline \multirow[b]{2}{*}{ Region } & \multirow{2}{*}{$\begin{array}{c}\text { Provenance } \\
\text { No. }\end{array}$} & \multicolumn{8}{|c|}{ Mean no. of cotyledons for seed mass classes $(\mathrm{mg})$ : } & \multirow{2}{*}{$\begin{array}{c}\text { Mean } \\
(\%)\end{array}$} & \multirow{2}{*}{$\begin{array}{l}\text { Seed mass } \\
\text { effect }^{a} \\
\quad(p>F)\end{array}$} \\
\hline & & $3.1-4.0$ & $4.1-5.0$ & $5.1-6.0$ & $6.1-7.0$ & $7.1-8.0$ & $8.1-9.0$ & $9.1-10.0$ & $10.1-11.0$ & & \\
\hline \multirow{6}{*}{$\begin{array}{l}\text { North } \\
\qquad\left(>55^{\circ} \mathrm{N}\right)\end{array}$} & 1 & 5.2 & 5.2 & 5.5 & 5.9 & & & & & 5.5 & 0.13 \\
\hline & 15 & 5.1 & 5.4 & 5.5 & & & & & & 5.4 & 0.12 \\
\hline & 2 & 4.9 & 4.9 & 5.3 & 5.6 & & & & & 5.2 & 0.09 \\
\hline & 26 & & & 5.1 & 5.4 & 5.6 & 5.8 & & & 5.5 & 0.07 \\
\hline & 27 & & 4.8 & 5.1 & 5.6 & 5.6 & & & & 5.2 & 0.17 \\
\hline & 4 & & 5.6 & 5.6 & 5.6 & 5.9 & & & & 5.7 & 0.64 \\
\hline \multirow{15}{*}{$\begin{array}{l}\text { Central } \\
\qquad\left(54-48^{\circ} \mathrm{N}\right)\end{array}$} & 5 & & 5.0 & 5.1 & 5.5 & 5.9 & & & & 5.4 & 0.002 \\
\hline & 6 & & & 5.5 & 5.9 & 5.9 & 5.9 & & & 5.8 & 0.49 \\
\hline & 10 & & & 4.6 & 5.4 & 6.0 & 5.7 & & & 5.5 & 0.27 \\
\hline & 11 & & & 5.7 & 5.9 & 6.2 & 6.3 & & & 6.0 & 0.08 \\
\hline & 9 & & 4.9 & 5.3 & 5.4 & 5.5 & & & & 5.3 & 0.05 \\
\hline & 7 & & & 5.7 & 5.3 & 5.8 & 5.8 & & & 5.7 & 0.50 \\
\hline & 23 & & & & & 5.9 & 5.8 & 6.3 & 6.1 & 6.1 & 0.07 \\
\hline & 8 & & 5.0 & 5.3 & 5.5 & 5.7 & & & & 5.4 & 0.02 \\
\hline & 13 & & & & & 5.8 & 6.3 & 6.4 & 6.7 & 6.3 & 0.08 \\
\hline & 22 & & & & 5.7 & 5.8 & 6.0 & 5.7 & & 5.8 & 0.58 \\
\hline & 12 & & 5.8 & 5.9 & 5.7 & 5.9 & & & & 5.8 & 0.63 \\
\hline & 25 & & & & 5.8 & 5.7 & 6.2 & 6.1 & & 5.9 & 0.21 \\
\hline & 21 & & & & & 5.7 & 6.0 & 6.3 & 6.2 & 6.0 & 0.38 \\
\hline & 14 & & & 5.2 & 5.3 & 5.8 & 6.2 & & & 5.6 & 0.58 \\
\hline & 16 & & & & 5.6 & 5.7 & 5.9 & 5.8 & & 5.8 & 0.37 \\
\hline \multirow{3}{*}{$\begin{array}{l}\text { South } \\
\qquad\left(<45^{\circ} \mathrm{N}\right)\end{array}$} & 19 & & & 5.6 & 5.8 & 5.9 & 5.9 & & & 5.8 & 0.70 \\
\hline & 18 & & & 5.9 & 6.0 & 6.0 & 6.2 & & & 6.1 & 0.36 \\
\hline & 20 & & & & 6.1 & 5.7 & 6.3 & 6.4 & & 6.1 & 0.06 \\
\hline Mean & & 5.1 & 5.2 & 5.5 & 5.7 & 5.8 & 6.0 & 6.1 & 6.4 & 5.7 & \\
\hline Population effect & & & & & & & & & & & \\
\hline$p>F$ & & 0.55 & 0.006 & 0.05 & 0.05 & 0.58 & 0.34 & 0.03 & 0.25 & 0.0001 & \\
\hline
\end{tabular}

${ }^{a}$ Based on analysis of variance of seed mass class effects within each population in this and subsequent tables. 
TABle 4. Mean length of cotyledons (cm) for European Scots pine populations in relation to variation in seed mass

\begin{tabular}{|c|c|c|c|c|c|c|c|c|c|c|c|}
\hline \multirow[b]{2}{*}{ Region } & \multirow{2}{*}{$\begin{array}{c}\text { Provenance } \\
\text { No. }\end{array}$} & \multicolumn{8}{|c|}{ Mean length of cotyledons for seed mass classes (mg): } & \multirow{2}{*}{$\begin{array}{c}\text { Mean } \\
\text { length } \\
(\mathrm{cm})\end{array}$} & \multirow{2}{*}{$\begin{array}{c}\text { Seed mass } \\
\text { effect } \\
(p>F)\end{array}$} \\
\hline & & $3.1-4.0$ & $4.1-5.0$ & $5.1-6.0$ & $6.1-7.0$ & $7.1-8.0$ & $8.1-9.0$ & $9.1-10.0$ & $10.1-11.0$ & & \\
\hline \multirow{6}{*}{$\begin{array}{l}\text { North } \\
\qquad\left(>55^{\circ} \mathrm{N}\right)\end{array}$} & 1 & 1.8 & 1.9 & 2.1 & 2.3 & & & & & 2.0 & 0.0002 \\
\hline & 15 & 1.8 & 2.0 & 2.1 & & & & & & 2.0 & 0.0002 \\
\hline & 2 & 1.6 & 2.0 & 2.0 & 2.3 & & & & & 1.9 & 0.01 \\
\hline & 26 & & & 2.1 & 2.2 & 2.3 & 2.6 & & & 2.3 & 0.06 \\
\hline & 27 & & 1.9 & 2.2 & 2.3 & 2.5 & & & & 2.2 & 0.005 \\
\hline & 4 & & 2.3 & 2.2 & 2.4 & 2.6 & & & & 2.4 & 0.05 \\
\hline \multirow{15}{*}{$\begin{array}{l}\text { Central } \\
\qquad\left(54-48^{\circ} \mathrm{N}\right)\end{array}$} & 5 & & 2.1 & 2.1 & 2.4 & 2.4 & & & & 2.3 & 0.008 \\
\hline & 6 & & & 2.4 & 2.5 & 2.7 & 2.7 & & & 2.6 & 0.08 \\
\hline & 10 & & & 2.0 & 2.2 & 2.5 & 2.8 & & & 2.4 & 0.29 \\
\hline & 11 & & & 2.2 & 2.3 & 2.5 & 2.6 & & & 2.4 & 0.10 \\
\hline & 9 & & 2.3 & 2.3 & 2.5 & 2.7 & & & & 2.5 & 0.002 \\
\hline & 7 & & & 2.4 & 2.5 & 2.7 & 2.8 & & & 2.6 & 0.02 \\
\hline & 23 & & & & & 2.8 & 2.7 & 3.0 & 3.2 & 2.9 & 0.02 \\
\hline & 8 & & 2.1 & 2.3 & 2.5 & 2.6 & & & & 2.4 & 0.004 \\
\hline & 13 & & & & & 2.3 & 2.5 & 2.9 & 2.7 & 2.6 & 0.20 \\
\hline & 22 & & & & 2.5 & 2.6 & 2.8 & 2.9 & & 2.7 & 0.006 \\
\hline & 12 & & 2.1 & 2.3 & 2.4 & 2.5 & & & & 2.3 & 0.07 \\
\hline & 25 & & & & 2.5 & 2.6 & 2.8 & 2.8 & & 2.7 & 0.11 \\
\hline & 21 & & & & & 2.4 & 2.7 & 2.8 & 2.7 & 2.6 & 0.15 \\
\hline & 14 & & & 2.3 & 2.6 & 2.6 & 2.7 & & & 2.5 & 0.02 \\
\hline & 16 & & & & 2.3 & 2.7 & 2.9 & 2.9 & & 2.7 & 0.0001 \\
\hline \multirow{3}{*}{$\begin{array}{l}\text { South } \\
\qquad\left(<45^{\circ} \mathrm{N}\right)\end{array}$} & 19 & & & 2.2 & 2.5 & 2.6 & 2.5 & & & 2.5 & 0.41 \\
\hline & 18 & & & 2.7 & 2.9 & 2.9 & 2.1 & & & 2.3 & 0.0003 \\
\hline & 20 & & & & 2.2 & 2.6 & 2.7 & 2.7 & & 2.6 & 0.0007 \\
\hline Mean & & 1.8 & 2.1 & 2.2 & 2.4 & 2.7 & 2.7 & 2.9 & 2.9 & 2.4 & \\
\hline Population effect & & & & & & & & & & & \\
\hline$p>F$ & & 0.33 & 0.007 & 0.04 & 0.002 & 0.005 & 0.37 & 0.38 & 0.05 & 0.0001 & \\
\hline
\end{tabular}


TABLE 5. Mean hypocotyl height (cm) for European Scots pine populations in relation to variation in seed mass

\begin{tabular}{|c|c|c|c|c|c|c|c|c|c|c|c|}
\hline \multirow[b]{2}{*}{ Region } & \multirow{2}{*}{$\begin{array}{c}\text { Provenance } \\
\text { No. }\end{array}$} & \multicolumn{8}{|c|}{ Mean hypocotyl height for seed mass classes (mg): } & \multirow{2}{*}{$\begin{array}{l}\text { Mean } \\
\text { height } \\
(\mathrm{cm})\end{array}$} & \multirow{2}{*}{$\begin{array}{c}\text { Seed mass } \\
\text { effect } \\
(p>F)\end{array}$} \\
\hline & & $3.1-4.0$ & $4.1-5.0$ & $5.1-6.0$ & $6.1-7.0$ & $7.1-8.0$ & $8.1-9.0$ & $9.1-10.0$ & $10.1-11.0$ & & \\
\hline \multirow{6}{*}{$\begin{array}{l}\text { North } \\
\quad\left(>55^{\circ} \mathrm{N}\right)\end{array}$} & 1 & 1.5 & 1.9 & 1.9 & 2.0 & & & & & 1.8 & 0.03 \\
\hline & 15 & 1.5 & 1.7 & 1.8 & & & & & & 1.7 & 0.0001 \\
\hline & 2 & 1.8 & 2.2 & 2.2 & 2.5 & & & & & 2.2 & 0.0004 \\
\hline & 26 & & & 2.2 & 2.3 & 2.6 & 2.5 & & & 2.4 & 0.41 \\
\hline & 27 & & 2.0 & 2.1 & 2.2 & 2.1 & & & & 2.1 & 0.74 \\
\hline & 4 & & 1.8 & 2.0 & 2.2 & 2.3 & & & & 2.1 & 0.005 \\
\hline \multirow{15}{*}{$\begin{array}{l}\text { Central } \\
\qquad\left(54-48^{\circ} \mathrm{N}\right)\end{array}$} & 5 & & 1.7 & 1.8 & 1.8 & 1.8 & & & & 1.8 & 0.61 \\
\hline & 6 & & & 2.1 & 2.1 & 2.7 & 2.5 & & & 2.2 & 0.04 \\
\hline & 10 & & & 2.0 & 1.8 & 2.3 & 2.0 & & & 2.0 & 0.28 \\
\hline & 11 & & & 1.8 & 2.1 & 2.2 & 2.2 & & & 2.1 & 0.03 \\
\hline & 9 & & 1.9 & 1.9 & 1.9 & 2.1 & & & & 2.0 & 0.17 \\
\hline & 7 & & & 2.1 & 2.1 & 2.3 & 2.3 & & & 2.2 & 0.17 \\
\hline & 23 & & & & & 2.4 & 2.5 & 2.6 & 2.5 & 2.5 & 0.21 \\
\hline & 8 & & 1.7 & 1.8 & 1.9 & 2.1 & & & & 1.9 & 0.11 \\
\hline & 13 & & & & & 2.4 & 2.5 & 2.7 & 2.5 & 2.6 & 0.38 \\
\hline & 22 & & & & 2.2 & 2.3 & 2.3 & 2.5 & & 2.3 & 0.06 \\
\hline & 12 & & 1.7 & 1.9 & 1.8 & 2.1 & & & & 1.9 & 0.05 \\
\hline & 25 & & & & 2.3 & 2.3 & 2.3 & 2.3 & & 2.3 & 0.98 \\
\hline & 21 & & & & & 2.3 & 2.3 & 2.4 & 2.2 & 2.3 & 0.44 \\
\hline & 14 & & & 1.8 & 2.2 & 2.2 & 2.5 & & & 2.2 & 0.15 \\
\hline & 16 & & & & 2.1 & 2.1 & 2.4 & 2.5 & & 2.3 & 0.008 \\
\hline \multirow{3}{*}{$\begin{array}{l}\text { South } \\
\qquad\left(<45^{\circ} \mathrm{N}\right)\end{array}$} & 19 & & & 2.2 & 2.3 & 2.6 & 2.6 & & & 2.4 & 0.01 \\
\hline & 18 & & & 2.0 & 2.2 & 2.3 & 2.3 & & & 2.2 & 0.41 \\
\hline & 20 & & & & 2.0 & 2.1 & 2.3 & 2.3 & & 2.1 & 0.15 \\
\hline Mean & & 1.6 & 1.8 & 2.0 & 2.1 & 2.2 & 2.4 & 2.5 & 2.5 & 2.1 & \\
\hline $\begin{array}{l}\text { Population effect } \\
\qquad p>F\end{array}$ & & 0.06 & 0.05 & 0.01 & 0.0002 & 0.0001 & 0.12 & 0.06 & 0.01 & 0.0001 & \\
\hline
\end{tabular}


The summer mean isotherm of $13^{\circ} \mathrm{C}$ is the temperature limit for good seed ripening in Scots pine, with marked deterioration in seed quality at mean summer temperatures below this (Shul'gin 1974). Seed mass also can vary locally among different types of forest associations, depending on site conditions and nutrient availability; in the most productive Scots pine forest types (linden-pine and hazelnut-pine) seed mass of Scots pine was one and a half times greater than in the least productive association Pinetum sphagnosum (Pravdin 1969). The presence of heavier seeds at southern latitudes may be explained by differences in moisture availability along the north-south latitudinal gradient. There is evidence that seeds tend to be larger in environments with a high risk of drought during seedling establishment (for review see Westoby et al. 1992).

Substantial variation in seed mass of Scots pine within a similar latitudinal range (Fig. 1) may also be influenced by environmental factors and year of collection (Urbanski 1978; Pulliainen and Lajunen 1984; Dormling and Johnsen 1992), age of mother trees (Kurdiani 1912; Giertych 1974; Bergsten 1985), size of cones, and their location on trees and place in the cone (Aldrich-Blake 1930; Sokolowski 1931; Eliason and Heit 1940; Zentsch 1961). Seed mass also varies with stand density and forest type (Cherepnin 1964) or in response to resin tapping (Paramonov 1970).

The mass of the seed coat, megagametophyte, and embryo increased in proportion to the mass of the seeds. Therefore, the partitioning of these parts in whole seeds was the same in the three populations (Fig. 3). Similar results were found for a population of Scots pine from central Poland (Wrzesniewski 1982). The mass of the megagametophyte and seed coat, which account together for $91 \%$ of seed mass (Fig. 3), are controlled mostly by the female parent and nonhereditary environmental factors (Righter 1945; Baumeister 1975). Therefore, the correlation between seed size and seedling size within a population is considered to be a temporary effect without genetic utility (Righter 1945). It has generally been found that across plant species, those with larger seeds tend to have a lower seedling relative growth rate (Westoby et al. 1992). In our study, this pattern was not found, perhaps because of the smaller range of seed mass (less than an order of magnitude) than across different species (more than several orders of magnitude).

For most populations germination percentage and time of emergence were not significantly related to seed mass. On average, the rate of emergence for all populations was similar and, therefore, without significant effects on early growth differences among populations. Based on our results, as well as on prior research, it is not possible to generalize about relations between seed mass and germination. For example, Dunlap and Barnett (1983) found that the size advantage of Pinus taeda $\mathrm{L}$. seedlings derived from large seeds was a consequence of their more rapid germination and emergence. For Pseudotsuga menziesii, such a correlation was found to be very weak (St. Clair and Adams 1991) and for Pinus sylvestris there was a lack of significant correlations in two studies (Zaborovskii 1966; Mikola 1985) but in another, a direct correlation between the rate of emergence and seed mass was found (Simak and Gustafsson 1954).

The mean number of cotyledons (5.7) and range (3-9) as well as their length $(1.9-2.9 \mathrm{~cm})$ were in the range reported for Scots pine (Pravdin 1969; Shutyayev 1979). In most populations, the size and number of cotyledons was strongly
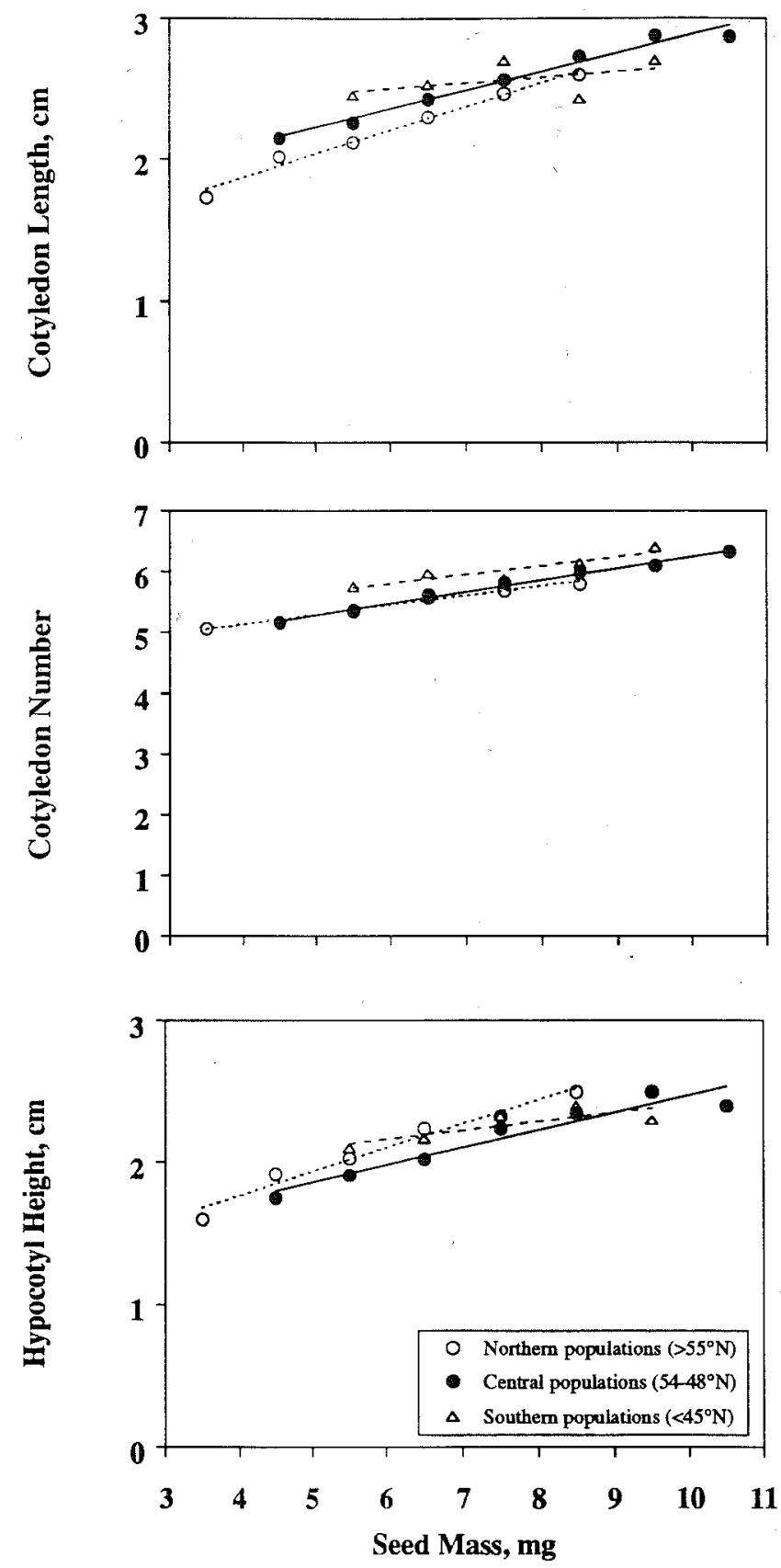

FIG. 5. Cotyledon length, cotyledon number, and hypocotyl height of 3-week-old seedlings of Scots pine in relation to seed mass variation within and among northern, central, and southern population groups.

positively affected by seed mass, which could contribute to higher initial growth of these plants. Schütt (1973) found that the detachment of some cotyledons after germination could reduce height growth, with effects sometimes evident even in the third growing season. Cotyledon mass is considered to be useful as an early testing method for predicting individual Scots pine growth (Schütt et al. 1969). Overall, there was a positive correlation between seed mass and the hypocotyl length $\left(r^{2}=0.50, p<0.01\right)$. A similar correlation was found by Mikola (1985) who examined relationships between seed mass and nursery-stage growth characteristics of 40 full-sib families of Scots pine from southern Finland. 
TABLE 6. Summary of ANOVA $p$-values for seed mass effects on dry mass components and proportional dry mass allocation for 1-year-old Scots pine seedlings grown under photoperiod conditions of 50 and $60^{\circ} \mathrm{N}$

\begin{tabular}{|c|c|c|c|c|c|c|}
\hline \multirow[b]{2}{*}{ Region } & \multirow{2}{*}{$\begin{array}{c}\text { Provenance } \\
\text { No. }\end{array}$} & \multicolumn{3}{|c|}{ Mass } & \multicolumn{2}{|c|}{ Allocation } \\
\hline & & Shoot ${ }^{a}$ & Root & Total plant & Root & Needle \\
\hline \multirow{6}{*}{$\begin{array}{l}\text { North } \\
\qquad\left(>55^{\circ} \mathrm{N}\right)\end{array}$} & 1 & 0.38 & $\underline{0.08}$ & 0.21 & 0.15 & 0.73 \\
\hline & 15 & $\underline{0.07}$ & $\overline{0.53}$ & 0.18 & 0.14 & 0.21 \\
\hline & 2 & $\overline{0.17}$ & 0.19 & 0.17 & 0.46 & 0.39 \\
\hline & 26 & 0.39 & 0.20 & 0.29 & 0.47 & 0.51 \\
\hline & 27 & 0.38 & 0.80 & 0.48 & 0.52 & 0.19 \\
\hline & 4 & 0.43 & 0.36 & 0.34 & 0.78 & 0.77 \\
\hline \multirow{15}{*}{$\begin{array}{l}\text { Central } \\
\qquad\left(54-48^{\circ} \mathrm{N}\right)\end{array}$} & 5 & $\underline{0.05}$ & $\underline{0.06}$ & $\underline{0.04}$ & 0.96 & 0.92 \\
\hline & 6 & 0.02 & 0.07 & $\overline{0.03}$ & 0.12 & 0.17 \\
\hline & 10 & $\overline{0.56}$ & 0.68 & 0.59 & 0.42 & 0.47 \\
\hline & 11 & $\underline{0.00}$ & $\underline{0.00}$ & $\underline{0.00}$ & 0.67 & 0.89 \\
\hline & 9 & 0.71 & 0.07 & 0.35 & 0.30 & 0.28 \\
\hline & 7 & $\underline{0.10}$ & $\overline{0.06}$ & $\underline{0.09}$ & $\underline{0.07}$ & $\underline{0.01}$ \\
\hline & 23 & $\overline{0.24}$ & 0.07 & $\overline{0.17}$ & $\overline{0.02}$ & 0.04 \\
\hline & 8 & 0.13 & $\overline{0.22}$ & 0.14 & $\overline{0.99}$ & 0.94 \\
\hline & 13 & 0.00 & 0.00 & 0.00 & 0.15 & 0.38 \\
\hline & 22 & $\underline{0.03}$ & 0.00 & $\underline{0.01}$ & 0.67 & 0.69 \\
\hline & 12 & 0.18 & 0.03 & 0.10 & 0.44 & 0.61 \\
\hline & 25 & 0.21 & $\overline{0.30}$ & 0.26 & 0.18 & 0.13 \\
\hline & 21 & 0.88 & 0.92 & 0.91 & 0.77 & 0.75 \\
\hline & 14 & 0.26 & 0.57 & 0.36 & 0.98 & 0.95 \\
\hline & 16 & 0.45 & 0.14 & 0.40 & 0.16 & 0.21 \\
\hline \multirow{3}{*}{$\begin{array}{l}\text { South } \\
\qquad\left(<45^{\circ} \mathrm{N}\right)\end{array}$} & 19 & $\underline{0.08}$ & $\underline{0.05}$ & $\underline{0.06}$ & 0.81 & 0.51 \\
\hline & 18 & $\overline{0.08}$ & $\overline{0.03}$ & $\underline{0.05}$ & 0.66 & 0.73 \\
\hline & 20 & 0.14 & $\underline{0.04}$ & 0.08 & 0.72 & 0.70 \\
\hline
\end{tabular}

NOTE: Analysis of variance of photoperiod and seed mass effects were conducted on each population separately. Only $p$-values for seed mass effects are shown. All seed mass effects on dry mass significant at $p<0.1$ had a positive correlation, and are underlined.

${ }^{a}$ Shoot mass is the sum of stem and needle dry mass.

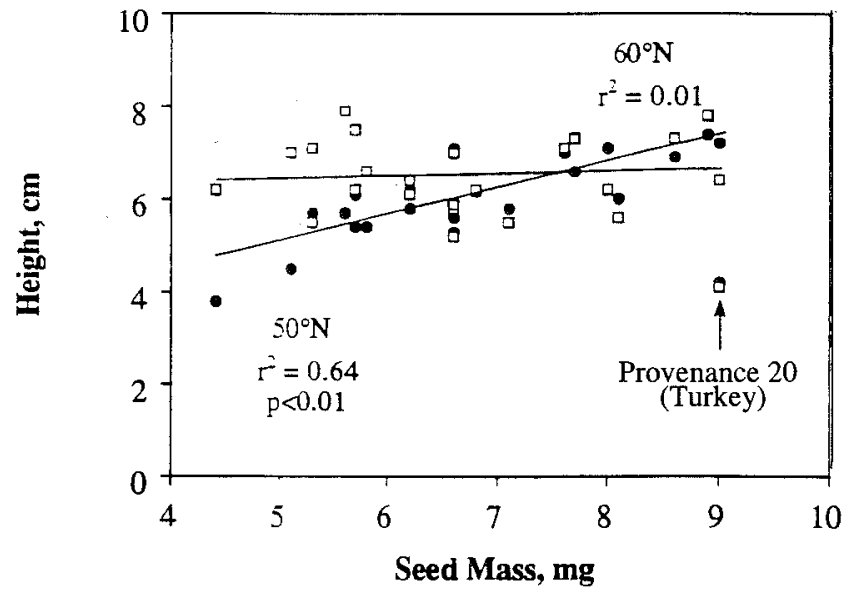

FIG. 6. Mean final height at the end of the first growing season among Scots pine populations in relation to mean population seed mass. Populations were grown under simulated photoperiod conditions of $50^{\circ} \mathrm{N}(\bullet, y=2.26+0.57 x)$ and $60^{\circ} \mathrm{N}(\square)$. Provenance 20 (Turkey) was excluded from the regressions.

At the end of the first growing season at the simulated 50 and $60^{\circ} \mathrm{N}$ photoperiods, seed mass did not influence biomass growth of northern Scots pine populations $\left(>55^{\circ} \mathrm{N}\right)$, but did affect 9 of 15 central populations (from 54 to $48^{\circ} \mathrm{N}$ ) and all southern $\left(<45^{\circ} \mathrm{N}\right)$ populations (Table 6$)$. Seed mass effects were more evident in root than shoot mass and less in biomass allocation. The fact that seed mass is better related to root than shoot growth could suggest that this adaptation presumably would benefit seedlings under drought conditions. However, we did not observe significant influence of seed mass on root allocation (Table 6), which has been suggested as an advantage for plants having larger seed, enabling their success under drought stress (Baker 1972). It is possible that allocational differences could occur at very early stages of seedling establishment that were not detected by us at the time of harvest at the end of the growing session.

In general, photoperiod effects on biomass growth and allocation were more pronounced (Oleksyn et al. 1992) than seed mass effects, and interactions were minimal. All populations showed greater aboveground biomass growth and lesser root allocation under long-day $\left(60^{\circ} \mathrm{N}\right)$ than short-day $\left(50^{\circ} \mathrm{N}\right)$ photoperiods. Detailed data and discussion on photoperiod related changes in growth, biomass partitioning, growth cessation, and possible existence of different photoperiodic ecotypes are presented elsewhere (Oleksyn et al. 1992).

The observed provenance differentiation in the relationship between seed mass and growth underscores the importance of source of plant material. A lack of seed mass and plant growth relationship in 1-year-old seedlings observed in several populations (Table 6) could explain why some studies found no association between these parameters (Borset 1951; Gailis 1973).

The existence of significant correlations between mean 
TABLE 7. Summary of linear regression analyses for seed mass effects on height growth of 1-year-old seedlings of Scots pine grown under photoperiod conditions of 50 and $60^{\circ} \mathrm{N}$ latitude

\begin{tabular}{|c|c|c|c|c|c|}
\hline \multirow[b]{2}{*}{ Region } & \multirow{2}{*}{$\begin{array}{c}\text { Provenance } \\
\text { No. }\end{array}$} & \multicolumn{2}{|c|}{$50^{\circ} \mathrm{N}$} & \multicolumn{2}{|c|}{$60^{\circ} \mathrm{N}$} \\
\hline & & $r^{2}$ & $p>F$ & $r^{2}$ & $p>F$ \\
\hline \multirow{6}{*}{$\begin{array}{l}\text { North } \\
\left(>55^{\circ} \mathrm{N}\right)\end{array}$} & 1 & $(+) 0.69$ & 0.17 & $(+) \underline{0.97}$ & 0.02 \\
\hline & 15 & $(+) 0.97$ & 0.11 & $( + ) \longdiv { 0 . 8 9 }$ & 0.22 \\
\hline & 2 & $(+) 0.98$ & 0.01 & 0.04 & 0.79 \\
\hline & 26 & 0.08 & 0.72 & 0.24 & 0.51 \\
\hline & 27 & 0.33 & 0.42 & 0.25 & 0.50 \\
\hline & 4 & 0.41 & 0.36 & 0.01 & 0.93 \\
\hline \multirow{15}{*}{$\begin{array}{l}\text { Central } \\
\qquad\left(54-48^{\circ} \mathrm{N}\right)\end{array}$} & 5 & $(+) 0.75$ & 0.13 & $(+) \underline{0.94}$ & 0.03 \\
\hline & 6 & $(-) 0.96$ & 0.02 & $(+) 0.67$ & 0.18 \\
\hline & 10 & 0.05 & 0.78 & 0.02 & 0.85 \\
\hline & 11 & $(+) 0.75$ & 0.13 & $(+) 0.52$ & 0.28 \\
\hline & 9 & $(+) 0.51$ & 0.29 & $(+) \underline{0.84}$ & 0.08 \\
\hline & 7 & $(+) 0.64$ & 0.20 & $\overline{0.01}$ & 0.92 \\
\hline & 23 & $(+) \underline{0.94}$ & 0.03 & 0.36 & 0.40 \\
\hline & 8 & 0.17 & 0.59 & 0.16 & 0.60 \\
\hline & 13 & $(+) 0.75$ & 0.13 & 0.01 & 0.93 \\
\hline & 22 & $(+) 0.61$ & 0.22 & $(+) 0.87$ & 0.06 \\
\hline & 12 & $(+) 0.87$ & 0.07 & 0.01 & 0.90 \\
\hline & 25 & $\overline{0.34}$ & 0.41 & 0.12 & 0.65 \\
\hline & 21 & 0.34 & 0.42 & $(-) \underline{0.86}$ & 0.07 \\
\hline & 14 & 0.39 & 0.38 & $\overline{0.19}$ & 0.56 \\
\hline & 16 & 0.25 & 0.50 & 0.46 & 0.32 \\
\hline \multirow{3}{*}{$\begin{array}{l}\text { South } \\
\left(<45^{\circ} \mathrm{N}\right)\end{array}$} & 19 & $(+) \underline{0.86}$ & 0.07 & 0.26 & 0.49 \\
\hline & 18 & 0.28 & 0.47 & $(+) 0.75$ & 0.13 \\
\hline & 20 & $(+) \underline{0.81}$ & 0.10 & $(+) \underline{0.99}$ & 0.01 \\
\hline
\end{tabular}

Note: $(+)$ and $(-)$ indicate positive or negative slopes of the linear regression between seed mass and height, for regressions with $r^{2}>0.5$. Relations significant at $p \leq 0.1$ and with $r^{2}>0.8$ are underlined.

TABLE 8. Correlation coefficients between mean seed mass and total height of European Scots pine populations at different field sites in Poland (Suprasl, Wyszkow, Rogow) and Croatia (Brezine-Alauci)

\begin{tabular}{|c|c|c|c|c|c|c|c|c|}
\hline \multirow[b]{2}{*}{$\begin{array}{c}\text { Age of } \\
\text { plants (years) }\end{array}$} & \multicolumn{2}{|c|}{ Suprasl $\left(53^{\circ} 12^{\prime} \mathrm{N}\right)^{a}$} & \multicolumn{2}{|c|}{ Wyszkow $\left(52^{\circ} 41^{\prime}\right)^{b}$} & \multicolumn{2}{|c|}{ Rogow $\left(51^{\circ} 47^{\prime}\right)^{c}$} & \multicolumn{2}{|c|}{$\begin{array}{l}\text { Brezine-Alauci } \\
\quad\left(\text { ca } 45^{\circ} \mathrm{N}\right)^{d}\end{array}$} \\
\hline & $\begin{array}{c}\mathrm{A} \\
(n=20)\end{array}$ & $\begin{array}{c}\mathrm{N} \\
(n=5)\end{array}$ & $\begin{array}{c}\mathrm{A} \\
(n=20)\end{array}$ & $\begin{array}{c}\mathrm{N} \\
(n=5)\end{array}$ & $\begin{array}{c}\mathrm{A} \\
(n=19)\end{array}$ & $\begin{array}{c}\mathrm{N} \\
(n=5)\end{array}$ & $\begin{array}{c}\mathrm{A} \\
(n=19)\end{array}$ & $\begin{array}{c}\mathrm{N} \\
(n=4)\end{array}$ \\
\hline 1 & $0.842 * * *$ & 0.853 & $0.703 * *$ & $0.848 *$ & 0.392 & 0.743 & - & - \\
\hline 2 & $0.760 * * *$ & 0.722 & $0.547 *$ & $0.942 *$ & 0.338 & 0.783 & $0.789 * * *$ & 0.821 \\
\hline 3 & $0.640^{* *}$ & $0.893^{*}$ & 0.317 & $0.980 * * *$ & - & - & $0.729 * * *$ & 0.548 \\
\hline 4 & $0.622 * *$ & $0.892^{*}$ & - & - & $0.484 *$ & 0.864 & $0.608 * *$ & 0.919 \\
\hline 5 & -0.003 & $0.939 *$ & 0.210 & $0.928 *$ & 0.203 & 0.870 & $0.562 *$ & 0.927 \\
\hline 6 & -0.111 & 0.849 & - & - & - & - & 0.409 & $0.978^{*}$ \\
\hline 7 & - & - & - & - & 0.191 & 0.820 & - & - \\
\hline
\end{tabular}

Note: A, all populations; $\mathrm{N}$, northern populations $\left(>55^{\circ} \mathrm{N}\right) . * * *, p<0.001 ; * *, p<0.01 ; *, p<0.05$.

${ }^{a}$ Rzeznik (1991).

${ }^{b}$ Kociecki (1985); S. Kociecki, unpublished data; Matras (1989).

${ }^{c}$ Gunia and Zybura (1987, 1989); Gunia et al. (1991).

${ }^{d}$ Gracan (1989), no precise latitude for field trial was indicated.

seed mass and 1-5 year old seedling height, as well as its gradual disappearance with time, in all but northern populations suggests that maternal seed effects may mask much of the real existing genetic variation in growth potential between populations during the early years of growth (Tables 8 and 9). The existence of a photoperiod effect on height growth (Fig. 6) may also affect the correlation of seed mass and height for plantation-grown seedlings. Height growth, especially among northern populations, is influenced by photoperiod (Oleksyn et al. 1992). Therefore, the strength of the height growth and seed mass relationships among all populations may be primarily due to the differential response of northern and central population groups to photoperiod, rather than seed mass differences, especially when examined in field plantations below ca $53^{\circ} \mathrm{N}$ latitude. Under field conditions, such factors as inherent differences in 
TABLE 9. Correlation coefficients between height of European Scots pine populations at different locations in Poland (Suprasl, Wyszkow, and Rogow) and Croatia (Brezine-Alauci)

\begin{tabular}{|c|c|c|c|c|c|c|c|c|c|c|c|c|c|c|c|c|c|c|c|}
\hline \multirow{3}{*}{$\begin{array}{l}\text { Location and } \\
\text { plant age } \\
\text { (years) }\end{array}$} & \multicolumn{19}{|c|}{ Location and plant age (years) } \\
\hline & \multicolumn{6}{|c|}{ Suprasl $\left(53^{\circ} 12^{\prime} \mathrm{N}\right)$} & \multicolumn{4}{|c|}{ Wyszkow $\left(52^{\circ} 41^{\prime} \mathrm{N}\right)$} & \multicolumn{5}{|c|}{ Rogow $\left(51^{\circ} 47^{\prime} \mathrm{N}\right)$} & \multicolumn{4}{|c|}{ Brezine-Alauci (ca. $45^{\circ} \mathrm{N}$ ) } \\
\hline & 1 & 2 & 3 & 4 & 5 & 6 & 1 & 2 & 3 & 5 & 1 & 2 & 4 & 5 & 7 & 2 & 3 & 4 & 5 \\
\hline \multirow{2}{*}{\multicolumn{20}{|c|}{ Suprasl }} \\
\hline $\begin{array}{l}1 \\
2\end{array}$ & $\overline{0.83} *$ & - & & & & & & & & & & & & & & & & & \\
\hline 3 & $0.76^{*}$ & $0.93 *$ & - & & & & & & & & & & & & & & & & \\
\hline 4 & $0.69 *$ & $0.89 *$ & $0.99 *$ & - & & & & & & & & & & & & & & & \\
\hline 5 & 0.17 & 0.28 & $0.56^{*}$ & $0.62 *$ & - & & & & & & & & & & & & & & \\
\hline 6 & 0.03 & 0.15 & 0.48 & $0.52^{*}$ & $0.97^{*}$ & - & & & & & & & & & & & & & \\
\hline \multicolumn{20}{|l|}{ Wyszkow } \\
\hline 1 & $0.88^{*}$ & $0.78^{*}$ & $0.75^{*}$ & $0.70^{*}$ & 0.33 & 0.24 & - & & & & & & & & & & & & \\
\hline 2 & $0.83 *$ & $0.64^{*}$ & $0.7^{*}$ & $0.64 *$ & 0.41 & 0.35 & $0.87 *$ & - & & & & & & & & & & & \\
\hline 3 & $0.62 *$ & 0.51 & $0.68^{*}$ & $0.64 *$ & $0.69 *$ & $0.64 *$ & $0.76^{*}$ & $0.82 *$ & - & & & & & & & & & & \\
\hline 5 & 0.43 & 0.35 & $0.61^{*}$ & $0.62^{*}$ & $0.86^{*}$ & $0.81 *$ & $0.58 *$ & $0.66 *$ & $0.91 *$ & - & & & & & & & & & \\
\hline \multicolumn{20}{|l|}{ Rogow } \\
\hline 1 & $0.66^{*}$ & 0.44 & 0.54 & 0.47 & 0.38 & 0.27 & $0.72^{*}$ & $0.73^{*}$ & $0.74 *$ & 0.61 & - & & & & & & & & \\
\hline 2 & $0.68^{*}$ & $0.60 *$ & $0.71^{*}$ & $0.67 *$ & 0.57 & 0.49 & $0.82 *$ & $0.83^{*}$ & $0.88^{*}$ & $0.77^{*}$ & $0.88^{*}$ & - & & & & & & & \\
\hline 4 & $0.66^{*}$ & $0.63^{*}$ & $0.74 *$ & $0.68^{*}$ & 0.42 & 0.35 & $0.71^{*}$ & $0.73^{*}$ & $0.64 *$ & 0.54 & $0.65^{*}$ & $0.75^{*}$ & - & & & & & & \\
\hline 5 & $0.57^{*}$ & 0.49 & $0.68 *$ & $0.64^{*}$ & $0.74 *$ & $0.69 *$ & $0.73^{*}$ & $0.76^{*}$ & $0.90^{*}$ & $0.87^{*}$ & $0.80^{*}$ & $0.94 *$ & $0.67 *$ & - & & & & & \\
\hline 7 & 0.46 & 0.41 & $0.64 *$ & $0.61^{*}$ & $0.82 *$ & $0.77^{*}$ & $0.65^{*}$ & $0.68^{*}$ & $0.89 *$ & $0.89^{*}$ & $0.75^{*}$ & $0.87^{*}$ & $0.58 *$ & $0.97^{*}$ & - & & & & \\
\hline \multicolumn{20}{|c|}{ Brezine-Alauci } \\
\hline 2 & $0.92 *$ & $0.77^{*}$ & $0.69 *$ & $0.62 *$ & 0.12 & 0.02 & $0.93^{*}$ & $0.83^{*}$ & $0.61^{*}$ & 0.39 & $0.65^{*}$ & $0.68 *$ & $0.68 *$ & 0.55 & 0.44 & - & & & \\
\hline 3 & $0.88^{*}$ & $0.73^{*}$ & $0.74 *$ & $0.70^{*}$ & 0.39 & 0.24 & $0.90^{*}$ & $0.82 *$ & $0.80^{*}$ & $0.66^{*}$ & $0.78^{*}$ & $0.82 *$ & $0.69 *$ & $0.72 *$ & $0.67 *$ & $0.87^{*}$ & - & & \\
\hline 4 & $0.86^{*}$ & $0.77^{*}$ & $0.83 *$ & $0.79 *$ & 0.55 & 0.42 & $0.93 *$ & $0.87^{*}$ & $0.88^{*}$ & $0.76^{*}$ & $0.79 *$ & $0.89 *$ & $0.73 *$ & $0.85^{*}$ & $0.77^{*}$ & $0.84 *$ & $0.94^{*}$ & - & \\
\hline 5 & $0.83 *$ & $0.76^{*}$ & $0.84^{*}$ & $0.80^{*}$ & $0.60^{*}$ & 0.48 & $0.92 *$ & $0.56^{*}$ & $0.90^{*}$ & $0.79^{*}$ & $0.79 *$ & $0.89 *$ & $0.72^{*}$ & $0.87 *$ & $0.81^{*}$ & $0.80^{*}$ & $0.92 *$ & $0.99 *$ & - \\
\hline 6 & $0.70^{*}$ & $0.66^{*}$ & $0.79 *$ & $0.75^{*}$ & $0.73^{*}$ & $0.64 *$ & $0.85^{*}$ & $0.82 *$ & $0.92^{*}$ & $0.84^{*}$ & $0.74 *$ & $0.88^{*}$ & $0.61^{*}$ & $0.93^{*}$ & $0.90^{*}$ & $0.68^{*}$ & $0.81^{*}$ & $0.93 *$ & $0.95^{*}$ \\
\hline
\end{tabular}

NoтE: The number of replications and sources of data are shown in Table $8 .{ }^{*} p<0.01$. 


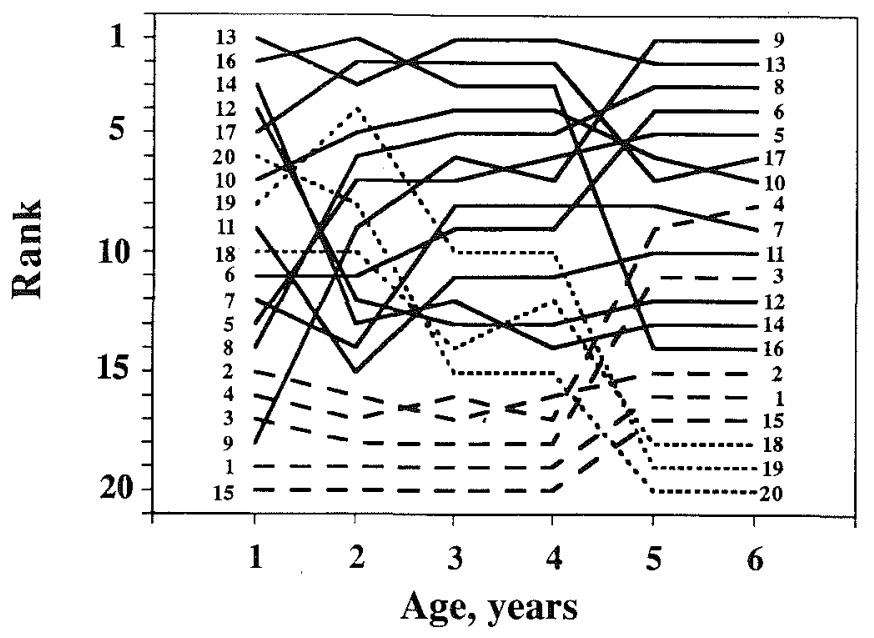

FIG. 7. Height ranking among Scots pine populations for each of 6 years in a common garden plantation in Supras1, Poland (drawn from data of Rzeznik 1991). Lines indicate changes in ranking over time, in northern (--), central (-), and southern (--) population groups.

pathogen and insect resistance, response to photoperiod, or response to other environmental factors, can eliminate initial seed mass related differences in seedling size, leading to a decrease with age of the correlations between maternal factors and progeny size (Perry 1976). These results show that the persistence of seed mass effects and differences in these effects among provenances, can affect practical conclusions of provenance experiments for at least 5 years.

\section{Acknowledgments}

The authors thank Professor Dr. G.I. Ryedko from St. Petersburg Forest-Technical Academy (Russia) for providing six seed sources (nos. 21-27), and the National Geographic Society (4435-90), National Academy of Sciences, USA, the National Science Foundation (IBN-9296005), and the University of Wisconsin for financial support.

Aldrich-Blake, R.N. 1930. The plasticity of the root system of Corsican pine in early life. Caledon Press, Dublin. Oxford For. Mem. 12.

Baker, H.G. 1972. Seed weight in relation to environmental conditions in California. Ecology, 53: 997-1010.

Baumeister, G. 1975. Möglichkeit der Früherkennung quantitativer Saatgutertragsleistungen bei Klonen von Pinus sylvestris L. in Samenplantagen. Silvae Genet. 24: 177-187.

Bergsten, U. 1985. Cone and seed properties in a young and old stand of Pinus sylvestris L. Stud. For. Suec. 168.

Birot, T. 1972. Variabilité intraspécifique du poids de la graine chez le Douglas (Pseudotsuga menziesii (Mirb.) Franco). Silvae Genet. 21: 230-243.

Borset, O. 1951. Research on progenies of individual trees from the coastal pine forest at Hvaler. [In Norwegian with English summary.] Medd. Nor. Skogforsoeksves. 11: 129-158.

Busse, J. 1931. Einfluß des Alters der Mutterkiefer auf ihre Nachkommenschaft. Mitt. Dtsch. Dendrol. Ges. 43: 63-74.

Campbell, R.K., and Sorensen, F.C. 1984. Genetic implications of nursery practices. In Forest nursery manual: production of bareroot seedlings. Edited by M.L. Duryea and T.D. Landis. Martinus Nijhoff/Dr. W. Junk Publishers, The Hague, Boston, Lancaster. pp. 183-191.

Chapin, F.S., III. 1980. The mineral nutrition of wild plants. Annu. Rev. Ecol. Syst. 11: 233-260.
Cherepnin, V.L. 1964. The importance of Pinus sylvestris seed origin, weight and colour in selection. In Selekciia Drevesnykh Porod v Vostochnoj Sibiri. [In Russian]. Izdatelstro Nauka, Moscow. pp. 58-68.

Dormling, I., and Johnsen, $\varnothing .1992$. Effects of the parental environment on full-sib families of Pinus sylvestris. Can. J. For. Res. 22: $88-100$.

Dunlap, J.R., and Barnett, J.P. 1983. Influence of seed size on germination and early development of loblolly pine (Pinus taeda L.) germinants. Can. J. For. Res. 13: 40-44.

Ehrenberg, C., Gustafsson, A., Plym-Forshell, C., and Simak, M. 1955. Seed quality and the principles of forest genetics. Hereditas, 41: 292-365.

Eliason, E.J., and Heit, C.E. 1940. The size of Scotch pine cones as related to seed size and yield. J. For. 38: 65-66.

Fober, H., and Giertych, M. 1968. Differentiation of Picea abies seedlings of Polish provenances as a function of the $\mathrm{N}$ content in the medium and the degree of competition from grass. Arbor. Kornickie, 13: 217-260.

Gailis, J.J. 1973. Correlation between the stem dimensions of Pinus sylvestris mother trees and the height of two-year halfsib seedlings. Lesovedenie, 6: 84-86.

Genys, J.B. 1968. Geographic variation in eastern white pine. Two-year results of testing range-wide collections in Maryland. Silvae Genet. 17: 6-12.

Giertych, M. 1974. Inadequacy of early tests for growth characters as evidenced by a 59-year-old experiment. In Proceedings, Joint IUFRO Meeting, S.02.04.1-3, Stockholm. Department of Forest Genetics, Swedish Royal College of Forestry, Stockholm. pp. 237-242.

Giertych, M., and Oleksyn, J. 1992. Studies on genetic variation in Scots pine (Pinus sylvestris L.) coordinated by IUFRO. Silvae Genet. 41: 133-143.

Gracan, J. 1989. International provenance experiment with Scots pine (Pinus sylvestris L.) in Blatusko Brdo II. [In SerboCroatian, with English summary.] Radovi, 24: 261-274.

Gunia, S., and Zybura, H. 1987. Growth, field survival and certain morphological characteristics of Scots pine (Pinus silvestris L.) plants of Polish and foreign provenances. Ann. Warsaw Agric. Univ. SGGW-AR For. Wood Technol. 36. pp. 69-77.

Gunia, S., and Zybura, H. 1989. European provenances of Scots pine (Pinus sylvestris L.) in comparative plantations in the experimental forest of Warsaw Agricultural University. [In Polish with English summary.] Sylwan, 133(11-12): 7-18.

Gunia, S., Zybura, H., and Buraczyk, W. 1991. Needle length and dry matter content compared with tree height of Scots pine (Pinus sylvestris L.) of European provenances in an experimental plantation in Central Poland. Ann. Warsaw Agric. Univ. SGGW-AR For. Wood Technol. 41: 69-77.

Hellum, A.K. 1976. Grading seed by weight in white spruce. Tree Plant. Notes, 27(1): 16-23.

Kociecki, S. 1985. Results of sowing Scots pine of various provenances in the SP IUFRO 1982 experiment. [In Polish with English summary.] Sylwan, 129(2): 44-52.

Kurdiani, S.Z. 1912. On the problem of pine seeds, harvesting from cones, and seed dryers. [In Russian.] Zap. NauchnoAleksandriiskogo Inst. 23(2).

Lindgren, D. 1982. Fractionation of seed orchard seeds by weight does have genetic implications. Silva Fenn. 16: 156-159.

Lines, R. 1974. A preliminary provenance trial with grand fir (Abies grandis Lindl.) Scott. For. 41: 69-77.

List, R.J. 1958. Smithsonian meteorological tables. Smithson. Misc. Collect. 111: 1-527.

Mann, W.F., Jr. 1979. Relationships of seed size, number of cotyledons, and initial growth of southern pines. Tree Plant. Notes, 30(2): 22-23.

Maschning, E. 1971. The variations in numbers of cotyledons in some provenances of Pinus contorta. Silvae Genet. 20: 10-14. 
Matras, J. 1989. Provenance studies on Scots pine conducted by the Section of Seed Science and Selection of the Forest Research Institute. [In Polish with English summary.] Sylwan, 123(11-12): 53-66.

Mikola, J. 1980. The effect of seed size and duration of growth on the height of Scots pine (Pinus sylvestris L.) and Norway spruce (Picea abies (L.) Karst.) provenances and progenies at the nursery stage. Silva Fenn. 14: 84-94.

Mikola, J. 1985. Relationship between height growth differences of Scots pine full-sib families and variation in seed size, annual growth rhythm, and some foliage characteristics. In Crop physiology of forest trees. Edited by P.M.A. Tiegerstedt, P. Puttonen, and V. Koski. Helsinki University Press, Helsinki, Finland. pp. 233-243.

Nanson, A. 1970. Juvenile and correlated trait selection and its effect on selection programs. In Proceedings, 2nd Meeting Working Group of Quantitative Genetics, Sec. 22, IUFRO, 18-19 Aug. 1969, Raleigh, N.C. USDA Forest Service, Southern Forest Experiment Station, New Orleans, La. pp. 19-26.

Oleksyn, J. 1988. Report on the IUFRO-1982 provenance experiment on Scots pine (Pinus sylvestris L.). Arbor. Kornickie, 33: $211-229$.

Oleksyn, J., Tjoelker, M.G., and Reich, P.B. 1992. Growth and biomass partitioning of populations of European Pinus sylvestris L. under simulated $50^{\circ}$ and $60^{\circ} \mathrm{N}$ daylengths: evidence for photoperiodic ecotypes. New Phytol. 120: 561-574.

Paramonov, E.G. 1970. The effect of tapping intensity on the seed production and seed quality of Scots pine. [In Russian.] Lesn. Zh. (Archangel, USSR), 13(1): 167-170.

Perry, T.O. 1976. Maternal effects on the early performance of tree progenies. In Tree physiology and yield improvement. Edited by M.G.R. Cannell and F.T. Last. Academic Press, London, New York, San Francisco. pp. 473-481.

Pravdin, L.F. 1969. Scots pine. Variation, intraspecific taxonomy and selection. Izd. Nauka, Moskva, 1964. [Translated from Russian by Israel Program for Scientific Translations, Jerusalem.]

Pulliainen, E., and Lajunen, L.H. 1984. Chemical composition of Picea abies and Pinus sylvestris seeds under subarctic conditions. Can. J. For. Res. 14: 214-217.

Righter, F.I. 1945. Pinus: the relationship of seed size and seedling size to inherent vigor. J. For. 43(2): 131-137.

Rzeznik, Z. 1991. Scots pine (Pinus sylvestris L.) of European provenances in the Suprasl forest inspectorate. [In Polish with English summary.] Rocz. Akad. Roln. Poznaniu Rozpr. Nauk. 219: $55-67$.

Saatçioglu, F. 1967. Results of the 25 years' provenance experiment established by using 16 Scotch pine of European and 1 of native provenances in Turkey. Silvae Genet. 16: 172-177.

Schotte, G. 1906. Tallkottens och tallfröets beskaffenhet skördeåret 1903-1904. [In Swedish.] Medd. Staten Skogsförsöksanstalt, 2: $175-180$.

Schotte, G. 1910. Om betydelsen af fröets hemort och moderädets ålder vid tallkultur. [In Swedish.] Medd. Staten Skogsförsöksanstalt, 7: 229-240.

Schütt, P. 1973. Ein Hinweis für Zusammenhänge zwischen
Cotyledonenzahl und Wuchsleistung bei Nadelholz-Sämlingen Forstw. Cbl. 92: 19-24.

Schütt, P., Neumann, P., and Schuck, H.-J. 1969. Zur quantitativen Morphologie von Konifern-Sämlingen. Forstwiss. Centralbl 88(3): $133-149$.

Shul'gin, V.A. 1974. Geographical variation of some characters and properties of Pinus sylvestris in the conditions of the Komi ASSR. [In Russian.] In Genetika, Selekcija, Semenovodstvo i Introduktsiya Lesnykh Porod, Gosudarstvennyi Komitet Lesnogo Khozyaistva Soveta Ministrov SSSR. pp. 163-176.

Shutyayev, A.M. 1979. Variation in the number of cotyledons in seedlings of pine and spruce. [In Russian with English summary.] Lesovedenie, 3: 56-62.

Silen, R., and Osterhaus, C. 1979. Reduction of genetic base by sizing of bulked Douglas-fir seed lots. Tree Plant. Notes, 30(11): 24-30.

Simak, M., and Gustafsson, А. 1954. Seed properties in mother trees and grafts of Scots pine. [In Swedish with English summary.] Medd. Statens Skogsforskningsinst. 44: 1-80.

Sindelar, J. 1974. Further information on the variability of Larix decidua. [In Czech with English summary.] Lesnictvi, 20: $625-644$.

Sokolowski, S. 1931. Biometrical studies concerning the races of Scots pine in Poland. [In Polish.] Prace Rolniczo-Lesne PAU, Krakow, 5: 1-106.

St. Clair, J.B., and Adams, W.T. 1991. Effects of seed weight and rate of emergence on early growth of open-pollinated Douglas-fir families. For. Sci. 37: 987-997.

Szczygiel, K. 1981. Effects of seed weight on height growth of Norway spruce seedlings under optimal conditions. Sylwan, 125(1): 33-39. (In Polish with English summary).

Tyszkiewicz, S. 1939. Evaluation of tree seeds. [In Polish.] Inst. Badania Lasow Panstw. Ser. A, 45: 1-176.

Urbanski, K. 1978. Effects of Scots pine seed weight from different trees on height growth of one-year-old seedlings. [In Polish with English summary.] Rocz. Akad. Roln. w Poznaniu Rozpr. Nauk. 96. pp. 159-167.

Westoby, M., Jurado, E., and Leishman, M. 1992. Comparative evolutionary ecology of seed size. Trends Ecol. Evol. 7(11): 368-372.

Wright, J.W., and Bull, W.I. 1963. Geographic variation in Scotch pine. Results of a 3-year Michigan study. Silvae Genet. 12: $1-25$.

Wrzesniewski, W. 1982. Physiology of Scots pine seedlings grown from seed of different weight. I. Differentiation of seed characteristics. Acta Physiol. Plant. 4(1-2): 31-42.

Zaborovskii, E.P. 1966. Analysis of cones and seeds of a single Scots pine tree. [In Russian.] Lesn. Zh. (Archangel, USSR), 9(6): 162-163.

Zentsch, W. 1961. Über Eigenschaften von Kiefernsaatgut aus verschiedenen Kronenregionen. Forstwiss. Centralbl. 80: 287-294.

Zheltov, N.M. 1974. Influence of seed size (weight) on Pinus sylvestris of the yield and quality of planting stock in nurseries. In Vliyanie Fiziko-Khimicheskich Factorov na Rastitel'nye Organizmy. [In Russian.] Tambov, USSR, pp. 13-17. 